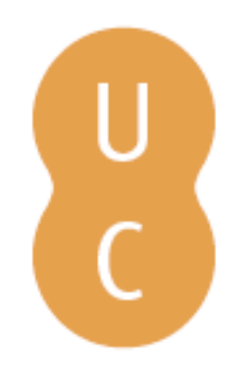

\title{
nombalina
}

\section{Laboratory measurement of transient carbon emissions from controlled smouldering peat fire}

\author{
Autor(es): $\quad$ Hu, Yuqi; Christensen, Eirik; Rein, Guillermo \\ Publicado por: Imprensa da Universidade de Coimbra \\ URL \\ persistente: URI:http://hdl.handle.net/10316.2/44700 \\ DOI: $\quad$ DOI:https://doi.org/10.14195/978-989-26-16-506_183 \\ Accessed : $\quad$ 26-Apr-2023 15:57:21
}

A navegação consulta e descarregamento dos títulos inseridos nas Bibliotecas Digitais UC Digitalis, UC Pombalina e UC Impactum, pressupõem a aceitação plena e sem reservas dos Termos e Condições de Uso destas Bibliotecas Digitais, disponíveis em https://digitalis.uc.pt/pt-pt/termos.

Conforme exposto nos referidos Termos e Condições de Uso, o descarregamento de títulos de acesso restrito requer uma licença válida de autorização devendo o utilizador aceder ao(s) documento(s) a partir de um endereço de IP da instituição detentora da supramencionada licença.

Ao utilizador é apenas permitido o descarregamento para uso pessoal, pelo que o emprego do(s) título(s) descarregado(s) para outro fim, designadamente comercial, carece de autorização do respetivo autor ou editor da obra.

Na medida em que todas as obras da UC Digitalis se encontram protegidas pelo Código do Direito de Autor e Direitos Conexos e demais legislação aplicável, toda a cópia, parcial ou total, deste documento, nos casos em que é legalmente admitida, deverá conter ou fazer-se acompanhar por este aviso.

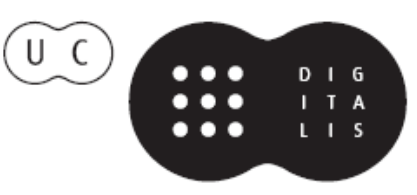




\section{ADVANCES IN}

\section{FOREST FIRE RESEARCH}

\section{8}

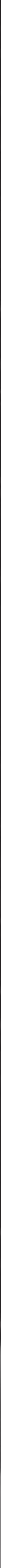


Short contribution - Decision Support Systems and Tools

\title{
Laboratory measurement of transient carbon emissions from controlled smouldering peat fire
}

\author{
Yuqi Hu; Eirik Christensen; Guillermo Rein* \\ ${ }^{1}$ Imperial College London, SW7 2AZ,UK, \{y.hu15@imperial.ac.uk, e.christensen16@imperial.ac.uk, \\ g.rein@imperial.ac.uk*\}
}

\begin{abstract}
Smouldering peat fires, the largest fires on Earth in terms of fuel consumed per unit surface, contribute a large fraction of greenhouse gas emissions to the atmosphere on an annual basis and are responsible for regional haze episodes. Haze induces severe air quality deterioration, vast economic losses and poses a threat to health of local communities. Emissions from smouldering peat fire have become an international concern, however, knowledge on this topic is poor. Remote sensing detection technologies developed from studies of flaming combustion become ineffective when applied to smouldering peat fires. This work investigates the transient emissions from smouldering peat fire through small-scale laboratory experiments. Oven dried moss peat sample was burned in an open-top horizontal reactor open-top reactor with a dimension of $20 \mathrm{~cm}$ by 20 $\mathrm{cm}$ in cross section and $10 \mathrm{~cm}$ in depth. The mass loss rate (MLR), the evolutions of mass flux and emission factors (EFs) of the most prominent carbon species $\left(\mathrm{CO}_{2}, \mathrm{CO}\right.$ and $\left.\mathrm{CH}_{4}\right)$ were measured. Three combustion stages identifying from the two MLR peaks were used to describe the varying combustion dynamics as the fire progresses. $\mathrm{CO}_{2}$ and $\mathrm{CO}$ are mainly emitted from char oxidation and present a similar emission evolution, whose mass fluxes peaked at the same time with the $2^{\text {nd }}$ MLR peak ( 120 min). Transient EFs of these two species increase monotonically as the proportion of char being oxidised increases throughout the experiments. In contrast, $\mathrm{CH}_{4}$ is mainly emitted from peat pyrolyis and it shows a different emission behaviour: both its mass flux and EFs peaked at the same time as the $1^{\text {st }}$ MLR peak $(\sim 30 \mathrm{~min})$, a time when intensified pyrolysis ends. This study helps understand the link between the smouldering peat combustion dynamics and the transient emissions. Recognising the different emission mechanisms among gas species can be useful in developing effective remote sensing and smouldering peat fire mitigation strategies to tackle this global challenge.
\end{abstract}

Keywords: remote sensing; wildfire; smouldering combustion; in-depth burning; transient emission

\section{Introduction}

Peatlands, the terrestrial ecosystems resulting from the accumulation of partially decayed vegetation, are vulnerable to smouldering combustion - the slow, low-temperature, flameless burning of porous fuels (Rein 2015). A smouldering fire can be initiated with a weak ignition source and sustained for very long periods despite firefighting attempts, extensive rains or weather changes (Rein 2013). Smouldering peat fire propagates both vertically and horizontally, rendering it a multidimensional burning phenomenon (Rein 2013; Huang et al. 2016). Carbon emissions derived from peat fires are equivalent to $15 \%$ of anthropogenic emissions, creating large perturbations to the global carbon cycle (Rein 2013). These fires are also responsible for regional haze (Rein 2013; Hu et al. 2018). Haze causes air quality deterioration, transportation disruption, and impaired visibility and induces surges of health emergencies in the population (Hu et al. 2018). The study of these fires using remote sensing is an important topic (Figure 1). Despite the diverse effects of emissions from smouldering peat, knowledge on this topic is limited to a handful of studies (Rein et al. 2009; Hu et al. 2018). This work provides insights into transient peat fire carbon emissions through controlled smallscale smouldering experiments. 


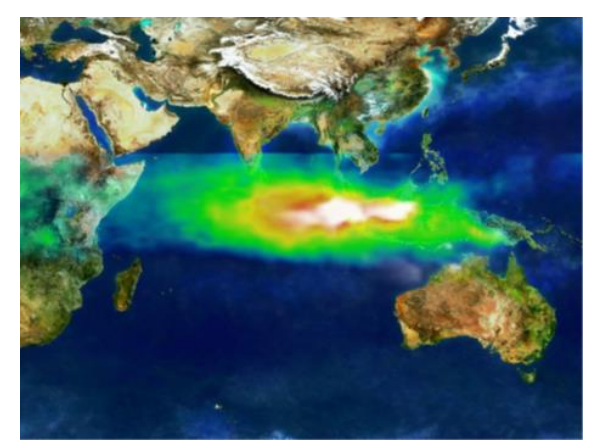

Figure 1 - Aerosol imaging by NASA satellite in October 1997 shows the vast smoke haze released by smouldering peat fires in Southeast Asia.

\section{Experimental method}

Roughly $0.88 \mathrm{~kg}$ of oven dried commercial peat was burned in an open-top reactor which has been used in previous smouldering study (Huang et al. 2016). A coil heater was used to ignite the peat by applying $100 \mathrm{~W}$ of power to the coil for $30 \mathrm{~min}$. Emissions from the smouldering peat were collected by an extraction hood under a steady extraction rate. The mass loss of the peat was recorded by a balance; the transient concentration of $\mathrm{CO} 2, \mathrm{CO}$ and $\mathrm{CH} 4$, the most prominent carbon emission species from peat fire, were measured by a Fourier-transform infrared spectroscopy (FTIR). The spread of the smouldering peat was monitored by a visual and an infrared camera. Each experiment lasted 8 hours and was repeated for 3 times.

\section{Results and discussion}

Mass flux and emission factor (EFs), the two most widely used parameters for biomass emission quantification, were calculated and discussed. Figure 2 shows the MLR of the dry peat as a function of the mass flux and EFs of $\mathrm{CO}_{2}$. It is seen that the combustion dynamics of the smouldering peat vary as the fire progresses.

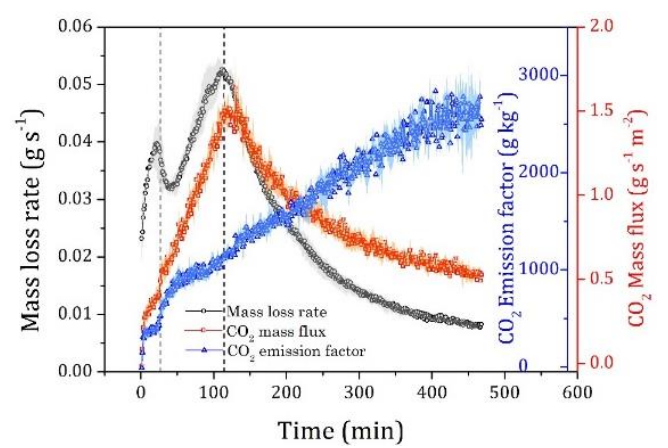

Figure 2 - Evolution of MLR, transient $\mathrm{CO}_{2}$ mass flux and EFs. The means and range (appeared as cloud) from all the 3 repeated smouldering peat experiments are shown. Vertical dashed line indicates the $1^{\text {st }}$ and $2^{\text {nd }}$ peak of the MLR of dry peat.

The MLR reached its first peak when the ignitor was turnt off $(\sim 30 \mathrm{~min})$. The $\mathrm{CO}_{2}$ mass flux peaked $\left(1.5 \mathrm{~g} \mathrm{~s}^{-1} \mathrm{~m}^{-2}\right)$ simultaneously with the the second peak of the MLR $(\sim 120 \mathrm{~min})$, a time when the surface peat was observed to spread to the far end of the reactor. $\mathrm{CO}_{2} \mathrm{EF}$ was found to increase monotonically throughout the experiments, reaching $\sim 2,500 \mathrm{~g} \mathrm{~kg}^{-1}$ at the end of the experiment. The comparison between MLR, mass flux and EFs indicates that the transient $\mathrm{CO}_{2}$ emissions are related with the combustion dynamics of the peat. 
Figure 3 shows the transient $\mathrm{CO}$ and $\mathrm{CH}_{4}$ emissions from smouldering peat. $\mathrm{CO}$ presents a similar evolution of mass flux and EFs with $\mathrm{CO}_{2}$, while for $\mathrm{CH}_{4}$, both the mass flux and EFs peaked at $\sim 30$ min, indicating a different emission mechanism.
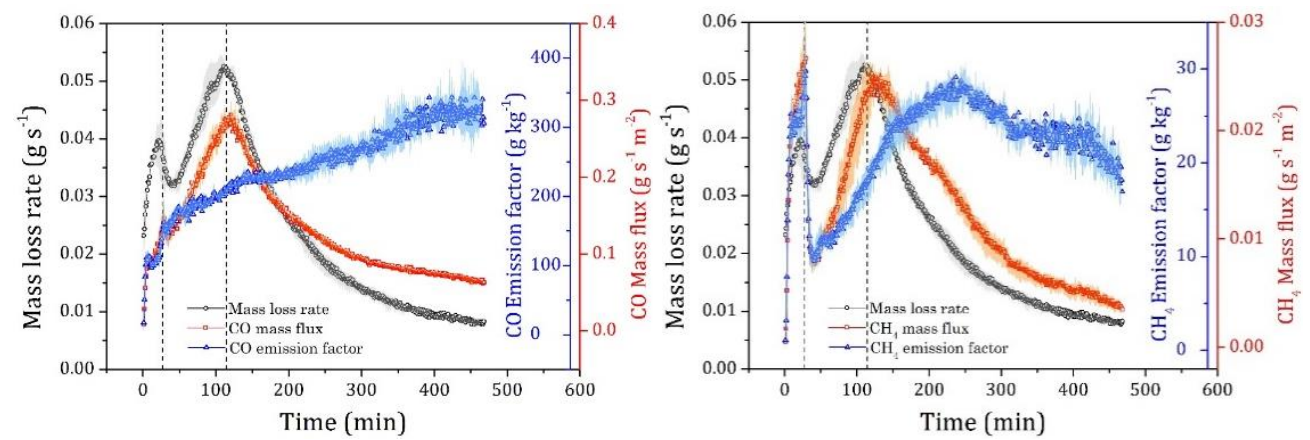

Figure 3 - Evolution of MLR, transient mass flux and EFs for $\mathrm{CO}$ (left) and $\mathrm{CH}_{4}$ (right).

\section{Conclusions}

Controlled laboratory experiments were carried out to investigate the transient emissions from smouldering peat. The results show that the mass loss rate, mass flux and emission factors of $\mathrm{CO}_{2}, \mathrm{CO}$ and $\mathrm{CH}_{4}$ vary as the fire progresses. The transient emissions are found to be related with the combustion dynamics. This work indicates that smouldering peat has different emission mechanisms among species, identifying these transient emissions could serve to develop effective remote sensing and mitigation strategies for peat fire.

\section{Acknowledgements}

The research has been funded by the China Scholarship Council (CSC) and the European Research Council (ERC) Consolidator Grant HAZE (682587).

\section{Reference}

G .Rein. "Smouldering Combustion,” In “The SFPE Handbook of Fire Protection Engineering”, 2016, (Ed Hurley MJ, pp. 581-603. Springer: New York).

G .Rein. "Smouldering Fires and Natural Fuels," In "Fire Phenomena and the Earth System: An Interdisciplinary Guide to Fire Science", 2013, (Ed Belcher CM, pp. 15-34. John Wiley \& Sons: Oxford).

X. Huang, F.Restuccia, M.Gramola, G. Rein. "Experimental study of the formation and collapse of an overhang in the lateral spread of smouldering peat fires", Combustion and Flame, 2016, 168, 393 402.

Y. Hu, N. Fernandez-Anez, T. E. L. Smith, and G. Rein. "Review of emissions from smouldering peat fires and their contribution to regional haze episodes", International Journal of Wildland Fire, 2018.

G. Rein, S.Cohen, A. Simeoni . "Carbon emissions from smouldering peat in shallow and strong fronts", Proceedings of the Combustion Institute, 2009, 32, 2489-2496. 